\title{
Letter: Cost-Effectiveness of Alectinib for Patients with Untreated ALK-Positive Non-Small-Cell Lung Cancer in China
}

\author{
Lifeng Mu (D) Benhong Zhou
}

Received: October 28, 2019 / Published online: January 4, 2020

(C) The Author(s) 2020

Keywords: Alectinib; China; Cost-effectiveness; Non-small-cell lung cancer; Oncology; Survival extrapolation

\section{Key Summary Points}

Long-term survival extrapolation should be used cautiously. The reliability of the model results should be fully demonstrated, and alternative parametric models should be taken into consideration in sensitivity analysis when long-term extrapolation is necessary.

All available evidence related to clinical efficacy should be considered in base-case analyses.

Dear Editor:

We read with great interest the original research entitled "Cost-effectiveness of alectinib for

Enhanced Digital Features To view enhanced digital features for this article go to https://doi.org/10.6084/ m9.figshare.11336849.

L. Mu · B. Zhou ( $\square)$

Department of Pharmacy, Renmin Hospital of

Wuhan University, Wuhan 430060, Hubei,

People's Republic of China

e-mail: benhongzh@whu.edu.cn patients with untreated ALK-positive non-small cell lung cancer in China" by Guan et al. [1] in Advances in Therapy. In this study, a Markov model developed in MS Excel was used to appraise the cost-effectiveness of alectinib compared with crizotinib in patients with untreated advanced anaplastic lymphoma kinase (ALK)-positive non-small-cell lung cancer (NSCLC) from the perspective of the Chinese healthcare system. In the basic case analysis, alectinib estimated an additional 1.04 QALY compared with crizotinib at an incremental cost of $\$ 54,827$, resulting in an incremental cost-benefit ratio (ICER) of $\$ 52,869$ / QALY. Clinical data from the ALESIA trial, a phase III clinical trial comparing alectinib with crizotinib in the Asian population, was considered in the scenario analysis, and the estimated ICER was $\$ 56,787 /$ QALY. Probabilistic sensitivity analysis (PSA) found that alectinib had only $0.4 \%$ probability of being cost-effective at a willingness to pay (WTP) of $\$ 28,109$, i.e., $3 \times$ the per capita GDP of China. Based on these results, the authors concluded that first-line treatment with alectinib in advanced ALK-positive NSCLC appears not to be cost-effective because of the high cost of drugs in China.

The treatment pathway considered in this article is based on the current available ALK inhibitors (including crizotinib, ceritinib and alectinib to date) and approved indications in China. Since the time to market in China is later 
than that of crizotinib and ceritinib, alectinib was not included in the National Reimbursement Drug List (NRDL) negotiation in 2018. In this negotiation, the prices of crizotinib and ceritinib were reduced by $70.52 \%$ (from $\$ 127.45$ to $\$ 37.57$ per $200 \mathrm{mg}$ ) and $60.41 \%$ (from $\$ 72.27$ to $\$ 28.63$ per $150 \mathrm{mg}$ ), respectively. Based on this, the authors fully considered the potential impact of the change in price of alectinib. These results are of practical significance for the management of ALK-positive NSCLC in China. Nevertheless, two aspects are worth exploring.

First, the supplementary data obviously show that the extrapolation of the various parameter survival models is quite different. Like in Figure A2-3 in Appendix 2 (a copy of Figure A2-3 with dotted lines and text annotation is provided at the end of this letter), the area under the curve (AUC) described by Gompertz and the exponential distribution are obviously different. In the presence of long-term extrapolation (a lifetime horizon), it is necessary to fully consider the influence of different parametric models on the result. In fact, concerns about data extrapolation are not uncommon in the field of health economics [2]. In this study, however, limited situations were considered: (1) exponential distribution was chosen for PFS and OS data in two arms; (2) Weibull distribution was chosen for the PFS of the alectinib group. Moreover, the authors did not explicitly give reasons for choosing these two cases for sensitivity analysis. In the model selection process, they considered a range of parameter survival models, including exponential, Weibull, Gompertz, log-logistic, log-normal and generalized gamma distribution. When different models are considered for clinical data in different treatment arms, there are bound to be many possible combinations. Here we believe that an analysis method based on script-based statistical software (such as R) is more advantageous. This can be done easily and reproducibly in a for-loop; the advantages of the script-based method the over Excel method have been fully discussed [3].

Second, the ALEX trial was the main source of clinical data, and data from the ALESIA trial were considered in the sensitivity analysis (based on the Asian population). However, the J-ALEX trial, another head-to-head phase III clinical trial for the efficacy and safety of alectinib and crizotinib in Japan, was not taken into account. In fact, efficacy and safety data were similar between Asian and non-Asian patients for alectinib and crizotinib [4]. Many RCTs have compared ALK inhibitors and chemotherapy for first-line treatment for ALK + NSCLC [5]. Therefore, results from a comprehensive decision analytical model [6] that fully considers direct and indirect evidence may be more robust.

In conclusion, we believe that results from long-term survival extrapolation should be fully investigated in sensitivity analysis to demonstrate the robustness of the model findings. It is necessary to construct a unified framework of evidence collection, evidence synthesis and cost-effectiveness analysis. Updating or reassessing will be convenient within a unified framework based on a script-based method when new evidence emerges or new ALK inhibitors are listed in China.

Figure A2-3 provided by Guan et al. in the Electronic supplementary material (with annotation)

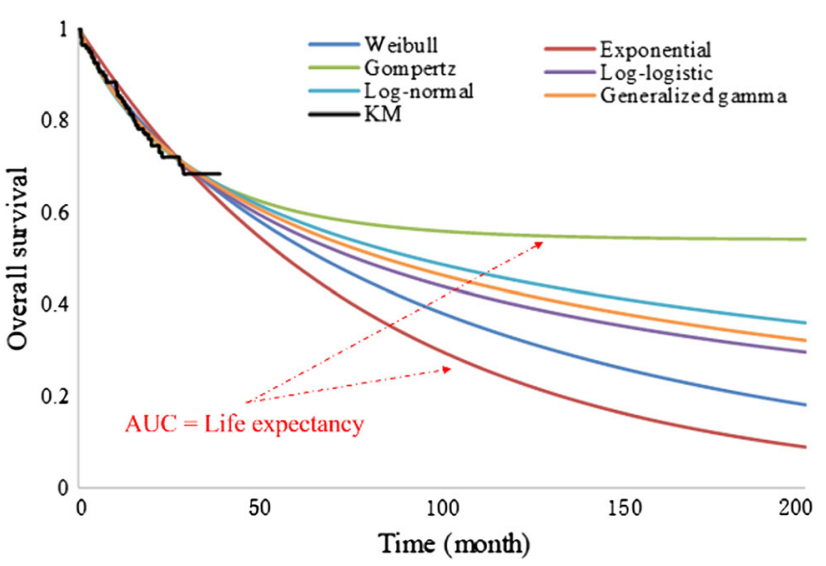

Sincerely Yours, Lifeng Mu.

\section{ACKNOWLEDGEMENTS}

Funding. No funding or sponsorship was received for this study or publication of this article. 
Authorship. All named authors meet the International Committee of Medical Journal Editors (ICMJE) criteria for authorship for this article, take responsibility for the integrity of the work as a whole, and have given their approval for this version to be published.

Disclosures. Neither Lifeng $\mathrm{Mu}$ nor Benhong Zhou have anything to disclose.

Compliance with Ethics Guidelines. This article is based on previously conducted studies and does not contain any studies with human participants or animals performed by any of the authors.

Peer Review. Please note, contrary to the journal's standard single-blind peer-review process, as a letter, this article underwent review by a member of the journal's Editorial Board.

Open Access. This article is licensed under a Creative Commons Attribution-NonCommercial 4.0 International License, which permits any non-commercial use, sharing, adaptation, distribution and reproduction in any medium or format, as long as you give appropriate credit to the original author(s) and the source, provide a link to the Creative Commons licence, and indicate if changes were made. The images or other third party material in this article are included in the article's Creative Commons licence, unless indicated otherwise in a credit line to the material. If material is not included in the article's Creative Commons licence and your intended use is not permitted by statutory regulation or exceeds the permitted use, you will need to obtain permission directly from the copyright holder. To view a copy of this licence, visit http://creativecommons.org/licenses/by$\mathrm{nc} / 4.0 /$.

\section{REFERENCES}

1. Guan H, Sheng Y, Guo W, Han S, Shi L. Costeffectiveness of alectinib for patients with untreated ALK-positive non-small cell lung cancer in China. Adv Ther. 2019;36(5):1114-25. https://doi.org/10. 1007/s12325-019-00908-7.

2. Guyot P, Ades AE, Beasley M, Lueza B, Pignon JP, Welton NJ. Extrapolation of survival curves from cancer trials using external information. Med Decis Mak. 2017;37(4):353-66. https://doi.org/10.1177/ 0272989X16670604.

3. Baio G, Heath A. When simple becomes complicated: why excel should lose its place at the top table. global $\&$ regional health technology assessment: Italian; Northern Europe and Spanish. SAGE J. 2016. https:// doi.org/10.5301/grhta.5000247.

4. Mok TSK, Peters S, Camidge DR, Ou SHI, Ahn JS, Tan EH, et al. 410O_PRAlectinib (ALC) vs crizotinib (CRZ) in treatment-naïve ALK + non-small-cell lung cancer (NSCLC): Asian vs non-Asian subgroup analysis of the ALEX study. Ann Oncol. 2017. https://doi.org/10. 1093/annonc/mdx729.009.

5. Fan J, Fong T, Xia Z, Zhang J, Luo P. The efficacy and safety of ALK inhibitors in the treatment of ALKpositive non-small cell lung cancer: a network metaanalysis. Cancer Med. 2018;7(10):4993-5005. https:// doi.org/10.1002/cam4.1768.

6. Cooper NJ, Sutton AJ, Abrams KR, Turner D, Wailoo A. Comprehensive decision analytical modelling in economic evaluation: a Bayesian approach. Health Econ. 2004;13(3):203-26. https://doi.org/10.1002/ hec. 804 . 